\title{
The expression of hACE2 receptor protein and its involvement in SARS-CoV-2 entry, pathogenesis, and its application as potential therapeutic target
}

\author{
Lobna Al-Zaidan ${ }^{\mathrm{a}, \mathrm{b}}$, Sarra Mestiri ${ }^{\mathrm{a}, \mathrm{b}}$, Afsheen Raza ${ }^{\mathrm{a}, \mathrm{b}}$, Maysaloun Merhi ${ }^{\mathrm{a}, \mathrm{b}}$, \\ Varghese Philipose Inchakalody ${ }^{\mathrm{a}, \mathrm{b}}$, Queenie Fernandes ${ }^{\mathrm{b}, \mathrm{d}}$, Nassiba Taib ${ }^{\mathrm{a}, \mathrm{b}}$, \\ Shahab Uddin ${ }^{\mathrm{c}}$ and Said Dermime ${ }^{\mathrm{a}, \mathrm{b}, *}$ \\ ${ }^{a}$ National Center for Cancer Care and Research, Hamad Medical Corporation, Doha, Qatar \\ ${ }^{\mathrm{b}}$ Translational Cancer Research Facility and Clinical Trial Unit, Interim Translational Research \\ Institute, Hamad Medical Corporation, Doha, Qatar \\ ${ }^{\mathrm{c}}$ Translational Research Institute, Hamad Medical Corporation, Doha, Qatar \\ ${ }^{\mathrm{d}}$ Qatar University Biomedical Research Center, Qatar University, Doha, Qatar
}

Received 24 December 2020

Accepted 4 July 2021

\begin{abstract}
Pneumonia cases of unknown etiology in Wuhan, Hubei province, China were reported to the World Health Organization on $31^{\text {st }}$ of December 2019. Later the pathogen was reported to be a novel coronavirus designated severe acute respiratory syndrome coronavirus 2 (SARS-CoV-2) that causes Corona virus disease 2019 (COVID-19). The disease outspread was followed by WHO declaration of COVID-19 pandemic as a "Public Health Emergency of International Concern". SARS$\mathrm{CoV}-2$ is a novel pathogenic beta coronavirus that infects humans causing severe respiratory illness. However, multifarious factors can contribute to the susceptibility to COVID-19 related morbidity and mortality such as age, gender, and underlying comorbidities. Infection initiates when viral particles bind to the host cell surface receptors where SARS-CoV-2 spike glycoprotein subunit 1 binds to the Angiotensin Converting Enzyme 2 (ACE2). It is of importance to mention that SARSCoV and SARS-CoV-2 viruses' mediate entry into the host cells via ACE2 receptor which might be correlated with the structural similarity of spike glycoprotein subunit 1 of both SARS viruses. However, the structural binding differs, whereas ACE2 receptor binding affinity with SARS-CoV-2 is 4 folds higher than that with SARS-CoV. Moreover, amino acids sequence divergence between the two S glycoproteins might be responsible for differential modulations of the specific immune response to both viruses. Identification of different aspects such as binding affinity, differential antigenic profiles of S-glycoproteins, and ACE2 mutations might influence the investigation of potential therapeutic strategies targeting SARS$\mathrm{CoV}-2 / \mathrm{ACE} 2$ binding interface. In this review, we aim to elaborate on the expression of hACE2 receptor protein and its binding with SARS-CoV-2 S1 subunit, the possible immunogenic sequences of spike protein, effect of ACE 2 polymorphism on viral binding, and infectivity/susceptibility to disease. Furthermore, targeting of hACE2 receptor binding with SARS-CoV-2 S1 subunit via various mechanisms will be discussed to understand its role in therapeutics.
\end{abstract}

Keywords: COVID-19, SARS-CoV-2, ACE2 receptor, spike glycoprotein, ACE2 polymorphism, S glycoprotein immunogenic sequences

\footnotetext{
*Corresponding author: Dr. Said Dermime, Senior Scientist/ Director of Translational Cancer Research Facility, National Center for Cancer Care and Research - Hamad Medical Corporation, Doha, PO Box. 3050, Qatar. Tel.: +974 50088752; +974 44390963; E-mail: sdermime@ hamad.qa. ORCID ID: 0000-0002-5526-7496
} 


\section{Introduction}

Idiopathic pneumonia cases in Wuhan, Hubei province, China were reported to the World Health Organization on 31st of December 2019 [1]. The pathogen was then reported to be a novel coronavirus designated severe acute respiratory syndrome coronavirus 2 (SARS-CoV-2) that causes Corona virus disease 2019 (COVID-19) [1, 2]. It was a severe blow to the world since the disease was transmitted like a wave all the way to the Americas from China. Therefore, WHO declared the COVID-19 outbreak a "Public Health Emergency of International Concern" [2]. As of 21 ${ }^{\text {st }}$ of June 2021, 178 million confirmed COVID-19 cases and 3.86 million deaths have been reported by WHO [2].

The initial spread of the virus was linked to Huanan seafood market in Wuhan resulting in subsequent human to human transmission [3]. Bats were believed to be the natural host of SARS-CoV-2 virus that crossed the species barriers via an intermediate host to infect humans. It was thought that beside pangolins and snakes, turtles (Pelodiscus sinensis, Chrysemys picta bellii, and Chelonia mydas) are also believed to be a potential intermediate hosts of SARS-CoV-2 [4].

SARS-CoV-2 is the seventh discovered coronavirus to infect humans. Coronaviruses are members of the Coronavirinae subfamily that ramify from the family Coronaviridae (International Committee on Taxonomy of Viruses). Coronavirinae subfamily comprises 4 genera (Alphacoronavirus, Betacoronavirus, Gammacoronavirus, and Deltacoronavirus). Only 7 viruses of Alphacoronavirus, and Betacoronavirus genera infect humans causing respiratory illness. However, SARS-CoV, MERS-CoV, and SARS-CoV-2 are three tremendously pathogenic $B$ coronaviruses that cause severe respiratory syndrome in humans [5].

SARS-CoV-2 is commonly known to mediate entry into the host cells through the ACE2 receptor [6]. The ACE2 receptor is known to be expressed on the alveolar epithelial cells in the lungs. Binding of the viral spike protein to the ACE2 receptor leads to subsequent fusion of the viral envelope and host cell membrane thereby allowing successful viral entry into the host cells [7, 8]. This binding of the virus to the ACE2 receptor leads to the endocytosis of lung alveolar epithelial cells causing irreversible damage to the lung tissue [9]. Following initial viral entry, cleavage between the S1 and S2 subunits of the viral glycoprotein takes places. This step is regulated by the receptor transmembrane protease serine 2 (TMPRSS2) that is a member of the Hepsin/TMPRSS subfamily [10]. Detachment of the S1 subunit from S2 causes the latter to undergo a conformational change that promotes and completes the fusion between the viral and host-cell membrane [11]. This fusion is a requisite for viral internalization, release of the viral content, replication, and subsequent infection of other cells. Therefore, due to the critical role hACE 2 binding with SARS-CoV-2, it is postulated that targeting of hACE2 by various mechanisms such as utilizing ACE inhibitors, blocking of $\mathrm{S}$ protein binding to ACE-2 by soluble recombinant human ACE2 protein, blocking ACE-2 receptor by antibodies or small molecules, inhibition of transmembrane protease serine 2 (TMPRSS2) activities, and generation of spike based protein vaccine could serve as a helpful therapeutic strategy.

In this review we aim to focus on the tissue distribution of hACE2 and its association with risk factors, structural binding mechanism of SARS-CoV-2 S1 subunit binding to human ACE2 that facilitates viral internalization, possible immunogenic sequences of spike protein, effect of ACE2 polymorphism on viral binding and infectivity/ susceptibility to disease. Furthermore, targeting of ACE2 will be discussed to understand its role in therapeutics.

\section{Tissue distribution of human angiotensin converting enzyme 2 (hACE2)}

It is of importance to elucidate the expression of ACE2 surface receptor in human organs to identify the potential routes of infection and possible passage processes of SARS-CoV-2 throughout the body. 
Although ACE2 mRNA expression was found in about 72 human tissues, ACE2 protein receptor was found to be remarkably expressed in limited number of cell types $[12,13]$. ACE2 receptor was found to be localized within the cilia of epithelial cells lining the airways as well as in the alveolar epithelial cells, thus suggesting the initial site of SARS-CoV-2 entry via respiratory transmission [13, 14]. Furthermore, ACE2 surface receptor within the digestive system is abundantly expressed in salivary gland, epithelial cells of the oral mucosa, and small intestine enterocytes, which might facilitate viral entry and contagiousness $[13,15,16]$. ACE2 receptor was also found to be highly expressed in the cholangiocytes of the liver as well as in the gallbladder epithelial cells [13, 17]. In addition, ACE2 expression was observed across several tissues in the kidney as in nephron epithelial cells, epithelial cells, endothelial cells, mesangial cells, and podocytes thus revealing kidneys susceptibility to COVID 19 infection and its disease-related complications [18, 19]. Reproductive system of both males and females showed high ACE2 expression particularly in the testes, spermatids, ovaries, fallopian tubes, placenta, uterus, and vagina thus revealing another mode of viral transmission [20, 21]. Moreover, ACE2 expression in the superficial ocular layers of conjunctiva, limbus, and cornea have shown high SARS-CoV-2 tropism in COVID 19 patients thus proposing novel routes of viral entry and transmission [22-24]. It is astonishing that adipose tissue comprises high ACE2 expression among all tissues which in turn explains why obesity is considered to be one of the risk factors for SARS-CoV-2 infection and disease progression [25]. On the other hand, high ACE2 expression in vascular endothelial cells and arterial smooth muscle cells could potentiate spreading of the virus to other body parts [13].

\section{Association between risk factors/ACE2 expression and susceptibility to SARS-COV-2}

\subsection{Chronic obstructive pulmonary disease patients (COPD)}

ACE2 was found to be abundantly expressed on the surface of alveolar epithelial cells [13]. It was reported that gene and protein expression of ACE2 in epithelial cells of COPD patients were significantly higher in comparison with non-COPD individuals thus facilitating SARS-CoV-2 entry [26]. However, ACE2 receptor was found to be downregulated upon SARS-CoV-2 infection thus determining the severity of the disease according to the degree of ACE2 deficiency [11]. ACE2 downregulation would markedly facilitate the progression of inflammatory lesions and embolism in the lower respiratory tract [11].

\subsection{Cardiovascular diseases}

Based on the reports from China and Italy, the history of prevalent cardiovascular diseases was observed to be the most common co-morbidity in addition to diabetes and hypertension [27-29]. In a particular study $4 \%$ of the infected subjects were found to have pre-existing cardiovascular diseases [28]. An interesting fact to note here is that most hypertension and cardiovascular patients may suffer from ACE2 deficiencies due to deletions or inhibitions; as stated by different studies [30-32]. Indeed, ACE2 deficiency was found to enhance susceptibility to heart failures [30]. Also, heterozygote loss of ACE2 has been linked to an increased incidence of heart disease [33]. Based on all the above evidences it is possible to state that ACE2 deficiencies may play a pivotal role in the pathogenesis of SARS-CoV- 2 infections. Under these given conditions, one may speculate that mild or moderate ACE2 deficiencies may actually display a protective effect against the virus; however, contrastingly, this is highly unlikely due to the high affinity of SARS-CoV-2 to ACE2 receptors $[34,35]$. However, such deficiencies mainly noted in cardiovascular patients amplifies the imbalance between ACE2 and ACE leading to progression of inflammatory and hyper-coagulation processes that further worsens the prognosis of SARS-COV-2 infections [36]. 


\subsection{Hypertension}

It was reported that among 20982 patients diagnosed with SARS-CoV-2 infection, 12.6\% were hypertension patients indicating that hypertension is one of the most prevalent comorbidities [37]. Among hypertension treatments, ACE inhibitors (ACEi) and angiotensin II receptor blockers (ARBs) are found to elevate the expression of hACE2 [38, 39]. Theoretically, this might facilitate the SAR-CoV2 uptake. However increased ACE2 expression and activity increases the conversion of angiotensin II (Ag II) to angiotensin 1-7 (Ang 1-7) protective anti-inflammatory peptide [40, 41].

Pulmonary ACE2 was found to be downregulated upon SARS-CoV-2 infection, thus enhancing Ang II release [42, 43]. Increased Ang II favors the Ang II / AT1R angiotensin II receptor 1 system over the ACE2 / Ang1-7 / mass system in the lung resulting in acute lung injury and subsequent ARDS Acute respiratory distress syndrome via AT1R [42]. Most importantly, available data up to date do not provide clear evidence whether hypertension or RAS blockers (ACEi and ARBs) favor the morbidity and/or the mortality of SARS-CoV-2 [44].

\subsection{Chronic kidney disease}

A meta-analysis shows that $83.93 \%$ of patients with CKD develop severe COVID-19 symptoms and that mortality was observed in $53.33 \%$ of the cases [45]. It has been reported that the ACE2 receptor is highly expressed in the kidney. Interestingly, RNA sequencing data from renal and respiratory tissues show that the ACE2 receptor expression in the kidney is 100-fold higher than that in the lung [46]. However, it is not clear whether SARS-CoV-2 replication occurs in these organs, possibly affecting their functional homeostasis.

\subsection{Diabetes}

Diabetic patients are often treated with ACE inhibitors (ACEi) and angiotensin receptor blockers (ARB). Interestingly, these drugs contribute to a markedly increase of ACE2 expression as an adaptive response to restrain the high level of angiotensin I and II [47]. Consequently, these ACE2 stimulating drugs would probably increase the risk to SARS-COV-2.

\subsection{Obesity}

Clinical reports from China [48], France [49] and the USA [50] suggested that obesity can be a risk factor for COVID-19 severity and related mortality due to the high prevalence of obese patients in critical condition. It has been reported that the expression level of ACE2 receptor is higher in the adipose tissue than in the lung tissue [51]. Therefore, having a more abundant adipose tissue than the normal population [52], obese individuals would possess a higher expression of ACE2 receptor and are consequently at a higher risk to SARS-CoV-2 infection [53]. In addition, once infected by SARS-COV-2, the adipose tissue can serve as a reservoir from which this virus could spread to other organs $[54,55]$.

\subsection{Smoking, elderly/Immuno-compromised Individuals}

Interestingly, a recent meta-analysis has revealed that pulmonary ACE2 expression was $25 \%$ higher in smokers compared to non-smokers [56]. Therefore, smoking might increase the risk of SARS-COV-2 infection via up-regulation of ACE2 receptor expression. 
Acute Respiratory Distress Syndrome (ARDS), the most common complication of SARS-CoV-2 infection was found to be more common in older patients [28]. Such a link between increasing age and severity of SARS-CoV-2 infections may be also attributed to the fact that ACE2 expression in the lungs decreases with increasing age [57]. Therefore, it may be speculated that ACE2 deficiencies in older individuals may also be one of the major reasons of increased severity of infection as in the case of cardiovascular patients.

\subsection{Gender}

Initial pandemic reports in China indicate that men are more susceptible to COVID-19 disease severity and related mortality than women [58-60]. Indeed, it has been shown that men represent $85 \%$ of the COVID-19 patients admitted in intensive care [60] and 70\% of the patients who died of COVID19 complications [61]. These findings can be explained by different biological differences between women and men. First, it has been confirmed that SARS-COV-2 uses the ACE2 receptor to invade the human cell and cause the final infection [9]. Interestingly, it has been reported that the density of ACE2 receptors in the reproductive organs is sex dependent. Indeed, the expression level of ACE2 receptors is much higher in testis than in the ovaries. Accordingly, a recent study suggests that the testis can serve as reservoir for SARS-COV-2 and that the testicular viral reservoirs play a crucial role in the viral persistence in men [62]. Furthermore, another study show that male reproductive systems are vulnerable to SARS-COV-2 infection and that COVID-19 patients show dramatic changes in sex hormones production due to the gonadal function impairment [63].

\subsection{Pregnant women and neonates}

Pregnancy also significantly increases the expression of ACE2 receptor in several organs such as kidney, uterus, placenta, and umbilical cord which thought to modulate hemodynamics during gestation [64-66]. ACE2 is also highly expressed in the ovary, oocytes, and vagina [67]. All of the foregoing facts mentioned contribute to SARS-CoV-2 virus infectivity and morbidity [67, 68]. Notably, ACE2 expression was found to be upregulated in heart, lung, and liver of human fetus which might pose severe pathological outcomes on neonates if infected by SARS CoV-2 virus [69].

\subsection{Cancer}

Consequently, active cancer patients infected with SARS-CoV-2 are more susceptible to severe clinical events compared to COVID-19 patients without cancer [70]. ACE2 is known to be an important regulator of lung function via protecting pulmonary tissue against injuries, therefore, its downregulation post SARS-CoV-2 infection can initiate severe immune responses and subsequent lung lesion. Reduced expression of ACE2 cause AT2 accumulation and AT1-7 dysregulation which consequently promotes inflammation. Indeed, ACE2 modulation is considered to be a major risk factor contributing to COVID19 severity in cancer patients [71-73].

A study by Winklet Tutilized data from The Cancer Genome Atlas (TCGA) and GTEx to compare the ACE2 mRNA levels between normal tissues (NT), normal tissues adjacent to tumors (NAT) and primary tumors (PT) and found that ACE2 mRNA levels in PT were significantly higher than in the respective normal tissue. On the other hand, ACE2 expression levels in NAT were also significantly higher than in NT across tissues/atleast as high as in the respective PT. This result suggests that the NAT of cancer patients would likely be more susceptible to SARS-CoV-2 infection than the corresponding tissues of healthy individuals. Furthermore, comparison of relative expression levels of ACE2 between healthy and tumor-adjacent lung tissues showed that ACE2 expression levels in the tumor-adjacent normal 
lung samples were significantly higher than those in the healthy normal lung samples indicating the possibility that lung cancer patients may have an increased risk to SARS-CoV-2 infection, regardless of chemotherapy-induced immune suppression [74]

\section{Structural binding of human ACE2 receptor to S1 protein}

ß Coronaviruses are enveloped viruses with four structural proteins known as Membrane glycoprotein (M), Spike protein (S), Nucleocapsid protein (N), and Envelope protein (E) [75]. Virion surface proteins such as the M, E, and S proteins in SARS-CoVs are well conserved [76, 77]. It is thought that E and M proteins are responsible for viral entry, replication, and particles assembly within the host cells [78]. However, viral infection is initiated via binding of viral particles to cellular surface receptors of the host cells where Spike glycoprotein (S) of SARS-CoV-2 virus recognize and bind to human angiotensin converting enzyme 2 (hACE2) [76].

Spike protein priming is essential for host cell entry and virus infectivity of SARS-CoV-2. Host TMPRSS2 mediates priming of the trimeric S protein thus cleaving it into S1 and S2 subunits at the S1/S2 furin-like multibasic cleavage site that harbors multiple arginine residues indicating high cleavability $[34,79]$. The $\mathrm{S} 1$ subunit of the spike protein was found to be responsible for binding host cell receptor hACE2 while S2 subunit contributes to viral and cellular membranes fusion [35, 80]. S1 subunit of the spike protein comprises both, $\mathrm{C}$ terminal domain (CTD) and $\mathrm{N}$ terminal domain (NTD). SARS-CoV-2 virus recognizes the hACE2 receptor via the CTD also known as receptor binding domain (RBD) [81].

Similar to other studied beta coronaviruses CTD structure shows two conserved subdomains [82]. One is the core subdomain that is composed of 5 inverse parallel beta strands $(\beta 1, \beta 2, \beta 3, \beta 4$, and B7) structure with a disulfide bond between $\beta 2$ and $\beta 4$ strands. The other subdomain is a conserved extended insertion of ( $\beta 5$ and $\beta 6$ strands, $\propto 4$ and $\propto 5$ helices, and loops) to the core subdomain forming the external subdomain that contains the receptor binding motif (RBM) which holds most of the binding residues of SARS-CoV-2 and hACE2 [76, 83].

There are 3 pairs of cysteine residues (Cys336 - Cys361, Cys379 - Cys432, and Cys391 - Cys525) in the RBD forming disulfide bonds to help in stabilizing the $\beta$ sheet structure and 1 pair (Cys480 Cys488) that facilitates connecting loops in the distal end of the RBD (Fig. 1a) [83].

The $\mathrm{C}$ terminal receptor binding domain of SARS-CoV-2 S1 subunit binds the $\mathrm{N}$ terminal subdomain I of hACE2 [84]. The $\mathrm{N}$ terminal subdomain I of hACE2 has 2 lobes where the external subdomain of SARS-CoV-2 binds the small loop, with a concave structure of RBM accommodating the $\mathrm{N}$ terminal helix of the hACE2 [83].

Two lysine residues (31 and 353) on hACE2 are essential for binding to SARS-CoV-2 which are known as binding hotspots found in the SARS-CoV-2 / hACE2 interface. Hotspot Lys31 forms a salt bridge with Glu35 and hotspot Lys353 forming a salt bridge with Asp38. Both salt bridges are weak due to the relatively long distance between both residues. However, the energy of salt bridges is enhanced when buried in a hydrophobic environment upon viral binding. This process is facilitated via hotspots interactions with adjacent RBD residues. The salt bridge in hotspot 31 breaks apart and each of Lys31 and Glu35 residues forms a hydrogen bond with Gln493 from SARS-CoV-2 RBM (Fig. 1b). In addition, the Asn501 residue within the SARS-CoV-2 RBM forms a hydrogen bond to the main chain of RBM to slightly stabilize hotspot Lys353 with the presence of Lys353Asp38 salt bridge (Fig. 1c) [85]. Several hydrophilic residues within SARS-CoV-2 / hACE2 interface were implicated in forming strong hydrogen bonds and salt bridge interactions. Those polar interlinkages include residue Ala475 of SARS-CoV-2-CTD interacting with Ser19 on hACE2, Asn487 with Gln24 (Fig. 1d), Glu484 with Lys31 (Fig. 1e), and Tyr453 with His34 (Fig. 1f) [76, 85]. The 


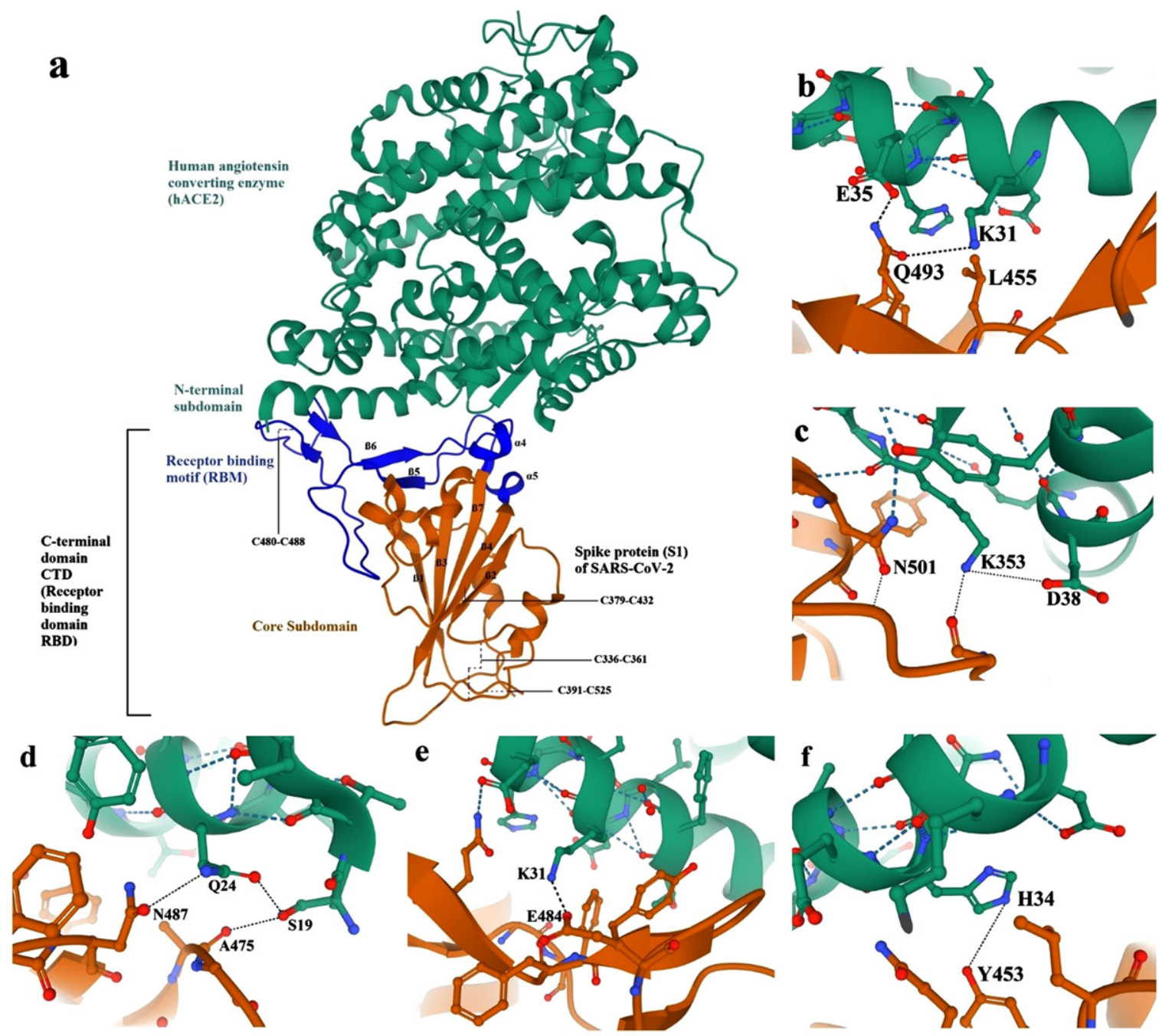

Fig. 1. SARS-CoV-2/hACE2 structure and detailed binding: a. Overall SARS-CoV-2/hACE2 complex monomer. (b, c, d, $\mathrm{e}$, and f) detailed structure of SARS-CoV-2 binding to human ACE2 receptor [76]. Human angiotensin converting enzyme (hACE2) in green, spike protein (S1) of SARS-CoV-2 core subdomain in orange, and spike protein (S1) of SARS-CoV-2 receptor binding motif $(\mathrm{RBM})$ in blue.

Phe486 and Tyr 489 of SARS-CoV-2 RBM interacts with Phe28, Leu79, Met82, and Tyr83 residues on hACE2 forming a hydrophobic pocket thus increasing the affinity of the virus to hACE2 receptor [76, $83,85]$.

The affinity between the ligand (SARS-CoV-2 S1) and the receptor (hACE2) reported in several studies by measuring the "dissociation constant $\mathrm{K}_{\mathrm{d}}$ " [76, 83]. Different dissociation constant values were reported due to variations in materials and methods used. $\mathrm{K}_{\mathrm{d}}$ Values were $\sim 15 \mathrm{nM}, 44.2 \mathrm{nM}$, $94.6+6.5 \mathrm{nM}$, and $4.7 \mathrm{nM}[76,83,85,86]$.

\subsection{Comparison between SARS-CoV-2 and SARS-CoV binding affinity to ACE2 receptor}

Overall studies revealed approximately four folds higher binding affinity between SARS-CoV-2 S1 subunit and hACE2 compared with SARS-CoV/hACE2. Cryo electron microscopy and X-ray 
$\mathbf{a}$
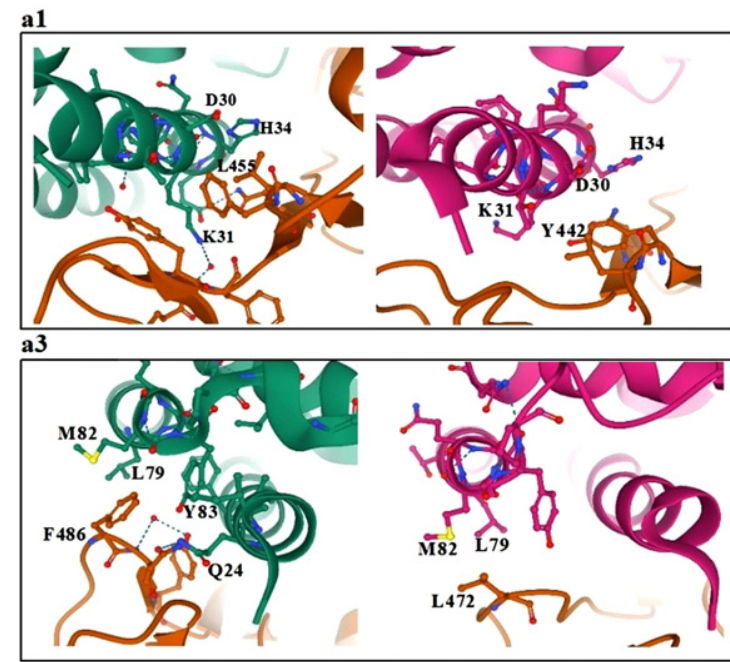

b

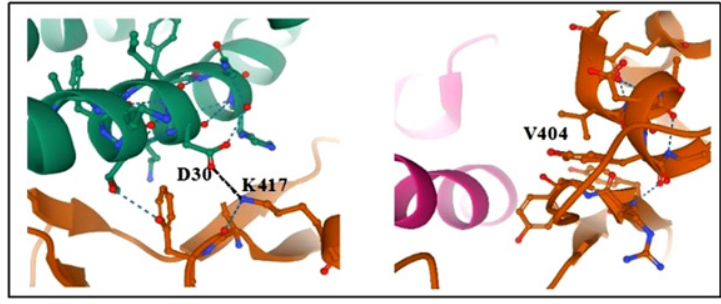

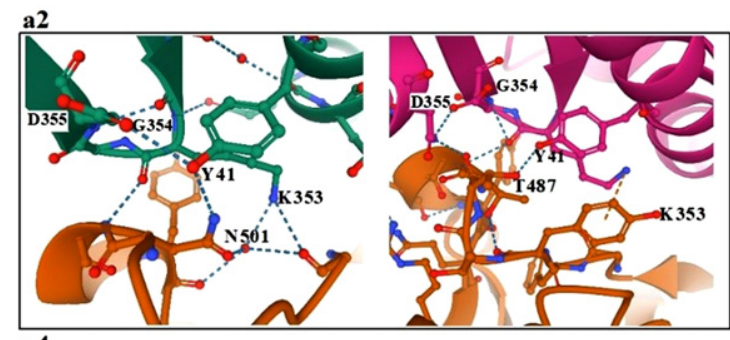

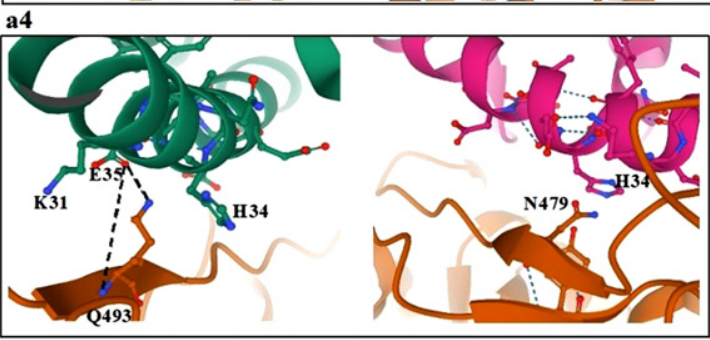

SARS-CoV-2 / hACE2

SARS-CoV / hACE2

Fig. 2. Comparison between SARS-CoV-2 and SARS-CoV binding hACE2 receptor. a. Interactions within the RBM of SARS-CoV-2 and SARS-CoV with hACE2 receptor. b. Variations in the K417/V404 position [76, 120].

crystallography techniques facilitated the discovery of viral receptor binding domain/ human ACE2 complex structure $[76,83,85]$. Although, receptor binding mode was in general similar in both ligands; SARS-CoV-2 RBM forms more atomic interactions with hACE2 thus increasing the binding affinity compared to the ligand between SARS-CoV and ACE2 receptor. The 35 and $\beta 6$ loop harbors the most variable region that facilitates stronger ionic and aromatic-aromatic interactions between SARS-CoV-2 and hACE2 compared to SARS-CoV loop [76].

When comparing the molecular interaction within the binding interface of the viral CTD, among the 24 residues of hACE2 that forms van der Waals forces (vdw) with residues of the virus CTD, 15 residues exhibit more contacts with SARS-CoV-2 CTD. Moreover, there are more residues on SARSCoV-2 that binds hACE2 compared to SARS-CoV (21 versus 17) that can form vdw interlinks (288 versus 213) in addition to higher hydrogen $(\mathrm{H})$ bonds interactions with SARS-CoV-2 than SARS-CoV (16 versus 11) [76]. The location that harbors the residues Leu455/Tyr442, SARS-CoV-2 Leu455 as SARS-CoV Tyr442 interact with the same residues on hACE2 Asp30, Lys31, and His34 (Fig. 2-a1) [76]. Hot spots Lys31 and Lys353 are critical in the binding of coronavirus RBD to hACE2. Lysine residues are stabilized where Asn501 on SARS-CoV-2 stabilizes hotspot 353/ Gln493 stabilize hotspot 31 which subsequently increase binding affinity of the novel virus [8]. Asn501 of SARS-CoV-2 and Thr487 of SARS-CoV, both interact with Tyr41, Lys353, Gly354, and Asp355 residues in hACE2 receptor (Fig. 2-a2) [83].

Phenylalanine residue Phe 486 in SARS-CoV-2 RBD interacts with residues (Gln24, Leu79, Met82, and Tyr83) on hACE2 forming a hydrophobic pocket that increases the binding affinity while in SARS$\mathrm{CoV}$ the corresponding residue is a leucine Leu472 side chain that provides a weaker interaction with (Leu79 and Met82) residues on hACE2 receptor (Fig. 2-a3) [76, 83, 85]. 
Glutamine residue Gln493 in SARS-CoV-2 interacts with Glu35, Lys31, and His 34 on hACE2 and forms a hydrogen bond with Glu35 while in SARS-CoV corresponding residue Asn479 interacts only with His34 on hACE2 (Fig. 2-a4) [83].

Finally, there is a unique residue Lys417 harbored in an external location outside SARS-CoV-2 RBM that forms a salt bridge link with hACE2 Asp30 (Fig. 2b) [83].

\section{Differential antigenic profile in the spike glycoprotein between SARS-CoV-2 and SARS-CoV}

Coronavirus entry into host cells is mediated by the transmembrane spike (S) glycoprotein which plays a major role in the stimulation of the anti-viral immune response [87]. This $\mathrm{S}$ glycoprotein includes 1255 amino acids (aa) [GenBank submission ID: AAP13441.1] [88] in SARS-CoV and 1273 aa in SARS-CoV-2 [GenBank submission ID: QHD43416.1][89]. In addition, S glycoprotein comprises two functional subunits; S1 and S2 subunits, which are respectively responsible for the binding to the host cell ACE2 receptor and for the fusion of the viral and host cellular membranes. Indeed, the S1 subunit contains the Receptor Binding Domain (RBD) which mediates the virus-host cell interaction through binding to the cell's ACE2 receptor [35]. Interestingly, it has been demonstrated that SARS-CoV and SARS-CoV-2 S glycoproteins show 25.2\% dissimilarity in the amino acids sequences [90]. In particular, a difference of $28 \%$ was observed at the Receptor Binding Domain residues [91]. Indeed, this RBD is located at the 318-569 aa sequence in SARS-CoV [GenBank submission ID: AAP13441.1][88] and at the 329-538 aa region in SARS-CoV-2 [GenBank submission ID: QHD43416.1][89]. This structural divergence between the two $\mathrm{S}$ glycoproteins might trigger changes in the antigenic properties of the two viruses leading to a differential modulation of the specific immune response.

Indeed, it has been demonstrated that most of the antibodies against SARS-CoV do not have a cross-neutralization activity toward SARS-CoV-2 [92]. Yet, the SARS-CoV viral epitopes targeted by the neutralizing antibodies are situated at the RBD [93]. Furthermore, a potent ACE2-blocking antiSARS-CoV neutralizing antibodies showed limited cross-binding and cross-neutralizing activities against SARS-CoV-2 [90]. In addition, two monoclonal antibodies m396, CR3014, developed against SARS-CoV did not show evident binding to SARS-CoV-2 RBD [92]. Another monoclonal antibody CR3022 against SARS-CoV has shown cross-reactivity against the RBD region of SARS-CoV-2 [92]. Crystal structure and interaction studies were performed using CR3022 and the SARS-CoV-2 RBD in order to determine the cross-reactive epitope at the RBD region in SARS-CoV and SARS-CoV-2. Interestingly, the mapping of the interacting region has shown that out of 28 residues, 24 (86\%) are conserved between SARS-CoV-2 and SARS-CoV. Thus, the presence of highly conserved sequences would explain the cross-reactivity of CR3022 between SARS-CoV-2 and SARS-CoV. However, in vitro binding affinity and micro-neutralization assays revealed that the antibody had higher affinity to SARS-CoV RBD and do not show any cross-neutralization activity between SARS-CoV-2 and SARS$\mathrm{CoV}$ [94]. Interestingly, a recent study has identified a novel human monoclonal antibody called 47D11 that neutralizes SARS-CoV and SARS-CoV-2 in vitro [95]. However, the neutralization assay was not confirmed in vivo and the mechanism of anti-viral activity is not fully described, yet it seems to be independent from receptor-binding interference [95].

The antigenic difference between SARS-CoV and SARS-CoV-2 spike glycoproteins has also been confirmed using patients' serum. Interestingly, cross-reactivity of antibodies isolated from plasma samples of SARS-CoV and SARS-CoV-2 infected patients was mostly observed at the non-RBD regions and especially at the Spike protein ectodomain. Despite the presence of cross-reactivity in binding, cross-neutralization activity was not detected in any of the plasma samples [96]. For instance, the SARS-CoV-2 epitopes targeted by antibody repertoires remain uncharacterized. Therefore, the 
identification of SARS-CoV-2 immunogenic epitopes, that induce the secretion of specific neutralizing antibodies, will present an opportunity to develop targeted therapeutic strategies that would enhance the patients' clinical prognosis and contain the spread of the virus. Indeed, immune response to viral pathogens is essential to recovery and an effective serotherapy may be the best tool to prevent the spread of COVID-19. However, the development of specific assays for the evaluation of the quality and the quantity of viral specific antibodies and the characterization of neutralizing antibodies is very critical to provide a successful passive immunization protocol such as convalescent plasma therapy. Convalescent plasma therapy is an immunotherapeutic strategy which was successfully used for the prevention and treatment of various infectious diseases including MERS and SARS-CoV. Indeed, plasma from patients who have recovered from COVID-19 contains high titers of neutralizing antibodies which would be used as promising treatment option for COVID-19 rescue [97]. For instance, Mapping of antibodies epitopes based on computational biology enabled the identification of formulated sequence-based epitopes scores in spike proteins of SARS-CoV and SARS-CoV-2 [98]. It has been shown that SARS$\mathrm{CoV}-2$ had significantly higher antibody epitope score compared with SARS-CoV. Moreover, sequence alignment studies revealed that the non-conserved regions had significantly higher antibody epitope score as well as higher surface epitope accessibility confirming that these domains of the spike proteins are more antigenic and more available for antibody recognition [98]. In addition, it has been shown that SARS-CoV-2 RBD presents higher affinity towards the ACE2 receptor than that of SARS-CoV. This is linked to the presence of a furin-like cleavage site restricted to SARS-CoV-2 [79].

Viral evolution has resulted in the appearance of new SARS-CoV-2 variants presenting mutations within the Spike glycoprotein, thus, increasing its binding affinity to ACE2 receptor. Indeed, a recent study reported that N501Y S protein mutation of the B.1.1.7 variant and L452R, E484Q mutations in B.1.617 have increased the binding energy of S protein/ACE2 binding when compared to wild type [99]. Altogether, different structural and functional characteristics could contribute to the increased infectivity of SARS-CoV-2 compared to SARS-CoV.

\subsection{Implication of ACE2 mutations on the viral binding}

The viral entry for SARS-CoV and SARS-CoV-2 is mediated through the interaction of the viral Receptor Binding Domain (RBD) with the ACE2 host cell membrane receptor [76]. The ACE2 gene is $40 \mathrm{~kb}$ long, contains 18 exons and is located at human X-chromosome [12]. ACE2 receptor is expressed by various human cells in the lung such as the airway and alveolar epithelial cells, the vascular endothelial cells and lung macrophages, as well as in brain cells and in cardiac, gastrointestinal and renal tissues [12]. Therefore, all these cells could be a target for SARS-CoV-2. ACE2 gene is highly polymorphic yet the effect of ACE2 mutation on the interaction with SARS-CoV-2 S glycoprotein is still not fully described.

Computational based analysis helped to identify around 400 different types of mutations in ACE2 protein among different populations. These mutations would affect the virus-host interaction pattern and affinity and thereby potentially alter host susceptibility. Indeed, some human ACE2 variants including S19P, I21V, E23K, K26R, T27A, N64K, T92I, Q102P and H378R are predicted to increase susceptibility to viral entry while other variants such as K31R, N33I, H34R, E35K, E37K, D38V, Y50F, N51S, M62V, K68E, F72V, Y83H, G326E, G352V, D355N, Q388L and D509Y are predicted to decrease binding to SARS-CoV-2 S glycoprotein [100]. However, according to the available data, at patient level, the ACE2 polymorphism is not affecting the viral infectivity [101]. The full-length cDNA of the ACE2 gene in the lung was sequenced and 19 single nucleotide polymorphisms (SNPs) were discovered. This polymorphism was compared in 44 SARS-CoV cases, 16 anti-SARS-CoV antibody positive contacts, 87 antibody negative contacts, and 50 non-contacts in Vietnam and there was no evidence that these polymorphism at ACE2 gene level are involved in the disease prognosis [102]. 
Polymorphism of ACE2 gene was observed in different populations and was associated with abnormal regulation of blood pressure and increased risk to develop hypertension. ACE2 levels also seem to be upregulated in men compared to women and in Asian individuals compared to Caucasian, American and African populations. ACE2 differential gene expression could have an impact on the susceptibility to COVID-19 and on the prognosis of this viral infection [103].

\section{Potential therapeutic targeting of angiotensin-converting enzyme 2}

ACE-2, having a critical role in the entry, replication, and pathogenicity of SARs-CoV-2, has been considered as a potential target for therapeutics. A number of clinical trials and pre-clinical studies focusing on various strategies including blocking of S protein binding to ACE-2 by soluble recombinant human ACE2 protein, blocking ACE-2 receptor by antibodies or small molecules, inhibition of transmembrane protease serine 2 (TMPRSS2) activities, utilizing ACE inhibitors and generation of spike based protein vaccine are underway worldwide (Table 1) [104].

Several studies have documented promising results targeting $S$ protein binding of ACE-2 by using recombinant human ACE2 (rhACE2) [105-108]. In vitro studies with soluble rhACE2 in cell culture and engineered replicas of human blood vessels/kidneys in organoids have shown that rhACE2 forms high affinity binding with receptor-binding domain of SARS-CoV-2 [106]. This leads to neutralization of $\mathrm{S}$ protein on the SARS-CoV-2 surface thus reducing viral cellular entry and thereby protecting the host from developing severe ARDS or acute lung injury (ALI) facilitated by its peptidase-dependent function $[105,106]$. On the other hand, ACE2 antibodies or peptides that selectively block the interaction site of SARS-CoV-2 with ACE2 have also been identified as potential therapeutic candidates [76]. In this, it has been proposed that the generation of ACE2 fusion protein with extracellular domain of the ACE2 to a human immunoglobulin G Fc domain could be used to facilitate SARS-CoV-2 Spike protein binding to this protein, thus blocking viral entry and replication [109, 110]. Furthermore, it has been suggested that if the effector function of Fc domain is, by some means, retained in the molecule, it could also allow recruitment of immune cells thus facilitating rapid activation of the host antiviral immune response and elimination of the virus. However, this ACE2-Fc strategy could have challenges such as mutating RNA virus may escape neutralization and increased levels of extracellular ACE2 could have implications in the host [111].

Recently, several studies have documented the role of antibodies interfering with Spike proteinACE-2 interactions [112, 113]. A study by Ge et al., described the structural and functional analyses of monoclonal antibodies from SARS-CoV-2 infected individuals. The authors observed that an antibody, labelled P2C-1F11, closely mimicked the binding of receptor ACE2 and was found to exhibit the most potent neutralizing activity in vitro. Furthermore, in Ad5-hACE2-sensitized mice, this antibody conferred strong protection against SARS-CoV-2 infection and triggered rapid and extensive shedding of S1 from the cell-surface expressed spike glycoprotein indicating its potency for neutralization via disruption of the critical steps for SARS-CoV-2 cell entry[114]. Another study by Chen et al., generated an ACE2-targeting monoclonal antibody,3E8, by immunizing BALB/c mice with Fc-tagged human ACE2 protein and screening the sera for binding to ACE2 and blocking SARS-CoV-2-S1-subunit/ACE2 interaction. It was observed that antibody $3 \mathrm{E} 8$ was the most potent neutralizing antibody and efficient blocker of S1-subunit/ACE2 binding indicating that 3E8 is a promising therapeutic candidate targeting human ACE2 molecule [115].

Inhibition of transmembrane protease serine 2 (TMPRSS2) activity is also considered an important strategy for blocking viral entry and replication [107]. Therefore, serine protease inhibitors of TMPRSS2 such as Camostat mesylate have been utilized in in vitro studies to study the effect on SARS-CoV-2 [116]. A recent study showed that Camostat mesylate significantly reduced the infection 
Table 1

On-going clinical trials focusing on ACE-2 in SARS-CoV-2 infection

\begin{tabular}{|c|c|c|c|c|}
\hline Trial ID; Country & Study title & Study type; Intervention & Enrolment eligibility & Primary expected outcome \\
\hline $\begin{array}{l}\text { NCT04324996, } \\
\text { China }\end{array}$ & $\begin{array}{l}\text { A Phase I/II Study of } \\
\text { Universal Off-the-shelf } \\
\text { NKG2D-ACE2 } \\
\text { CAR-NK Cells for } \\
\text { therapy of COVID-19 }\end{array}$ & $\begin{array}{l}\text { Intervention; } \\
\text { Intravenous infusion of constructed } \\
\text { NKG2D-ACE2 CAR-NK cells secreting } \\
\text { super IL15 superagonist and GM-CSF } \\
\text { neutralizing scFv }\end{array}$ & $\begin{array}{l}\text { Common, severe and } \\
\text { critical pneumonia }\end{array}$ & $\begin{array}{l}\text { Efficacy, safety and tolerability of treatment } \\
\text { with NKG2D-ACE2 CAR-NK cells }\end{array}$ \\
\hline $\begin{array}{l}\text { NCT04328012, } \\
\text { United States }\end{array}$ & $\begin{array}{l}\text { Comparison of } \\
\text { therapeutics for } \\
\text { hospitalized patients } \\
\text { Infected with } \\
\text { SARS-CoV-2 } \\
\text { (COVIDMED) }\end{array}$ & $\begin{array}{l}\text { Randomized, double blind, Phase 2; } \\
\text { Group 1: Losartan (Angiotensin II receptor } \\
\text { blocker) } \\
\text { Group2: Hydroxychloroquine Sulfate } \\
\text { (anti-malarial) } \\
\text { Group3: Lopinavir/ritonavir (antiretroviral) } \\
\text { Group 4: Placebo }\end{array}$ & $\begin{array}{l}\text { Hospitalized patients } 72 \\
\text { hrs prior to } \\
\text { randomization }\end{array}$ & $\begin{array}{l}\text { Difference in National Institute of Allergy } \\
\text { and Infectious Diseases COVID-19 Ordinal } \\
\text { Severity Scale (NCOSS) between different } \\
\text { treatment groups }\end{array}$ \\
\hline $\begin{array}{l}\text { NCT04355936, } \\
\text { Argentina }\end{array}$ & $\begin{array}{l}\text { Telmisartan for Treatment } \\
\text { of COVID-19 Patients }\end{array}$ & $\begin{array}{l}\text { Randomized, Open label, Phase } 2 \\
\text { Group 1:Telmisartan (Angiotensin II receptor } \\
\text { blocker) plus standard care } \\
\text { Group 2: standard care alone }\end{array}$ & $\begin{array}{l}\text { PCR confirmed } \\
\text { SARS-CoV-2 infection }\end{array}$ & $\begin{array}{l}\text { Development of acute respiratory distress } \\
\text { syndrome (blood oxygen saturation below } \\
93 \% \text { ) within } 15 \text { days of enrolment between } \\
\text { different treatment groups }\end{array}$ \\
\hline $\begin{array}{l}\text { NCT04335786, } \\
\text { Netherlands }\end{array}$ & $\begin{array}{l}\text { Valsartan for Prevention } \\
\text { of ARDS in } \\
\text { Hospitalized Patients } \\
\text { with SARS-COV-2 } \\
\text { (COVID-19) }\end{array}$ & $\begin{array}{l}\text { Randomized, double blind, Phase } 4 \\
\text { Group1: Valsartan ((Angiotensin II receptor } \\
\text { blocker) } \\
\text { Group 2: Placebo }\end{array}$ & Hospitalized patients & $\begin{array}{l}\text { Occurrence within } 14 \text { days of randomization } \\
\text { of either: ICU admission;) mechanical } \\
\text { ventilation or death }\end{array}$ \\
\hline
\end{tabular}




\begin{tabular}{|c|c|c|c|c|}
\hline $\begin{array}{l}\text { NCT04329195, } \\
\text { France }\end{array}$ & $\begin{array}{l}\text { ACE Inhibitors or ARBs } \\
\text { Discontinuation in } \\
\text { Context of } \\
\text { SARS-CoV-2 Pandemic } \\
\text { (ACORES-2) }\end{array}$ & $\begin{array}{l}\text { Randomized, Open label, Phase } 3 \\
\text { Group 1: Discontinuation of RAS blocker } \\
\text { (ACE inhibitor) therapy } \\
\text { Group 2: Continuation of RAS blocker (ACE } \\
\text { inhibitor) }\end{array}$ & $\begin{array}{l}\text { Hospitalized patients } \\
\text { chronically treated with } \\
\text { RAS blockers prior to } \\
\text { admission with a } \\
\text { treatment duration } \geq 1 \\
\text { month }\end{array}$ & $\begin{array}{l}\text { Time to clinical improvement from day } 0 \text { to } \\
\text { day } 28 \text { between different treatment groups }\end{array}$ \\
\hline $\begin{array}{l}\text { NCT04348695, } \\
\text { Spain }\end{array}$ & $\begin{array}{l}\text { Study of Ruxolitinib Plus } \\
\text { Simvastatin in the } \\
\text { Prevention and } \\
\text { Treatment of } \\
\text { Respiratory Failure of } \\
\text { COVID-19. } \\
\text { (Ruxo-Sim-20) }\end{array}$ & $\begin{array}{l}\text { Randomized, Open label, Phase } 2 \\
\text { Group 1: Ruxolitinib plus simvastatin (ACE } \\
\text { inhibitor) } \\
\text { Group 2: Standard of care }\end{array}$ & $\begin{array}{l}\text { Hospitalized patients } \\
\text { with grade } 3 \text { or } 4 \text { of the } \\
\text { WHO 7-point ordinal } \\
\text { scale of severity } \\
\text { categorization for } \\
\text { COVID-19 }\end{array}$ & $\begin{array}{l}\text { Percentage of patients who develop severe } \\
\text { respiratory failure (grade } 5 \text { or higher of the } \\
\text { WHO 7-point ordinal scale of severity } \\
\text { categorization) within } 7 \text { days of } \\
\text { randomization. }\end{array}$ \\
\hline $\begin{array}{l}\text { NCT04337190, } \\
\text { France }\end{array}$ & $\begin{array}{l}\text { Impact of Angiotensin II } \\
\text { Receptor Blockers } \\
\text { treatment in Patients } \\
\text { with COVID-19 } \\
\text { (COVID-ARA2) }\end{array}$ & $\begin{array}{l}\text { Observational } \\
\text { Blood sampling at the day of admission, day } \\
3 \text { and day } 7\end{array}$ & $\begin{array}{l}\text { Intensive care unit } \\
\text { admitted patients with } \\
\text { ARDS }\end{array}$ & ACE2 level change over time \\
\hline $\begin{array}{l}\text { NCT04331574, } \\
\text { Italy }\end{array}$ & $\begin{array}{l}\text { Renin-Angiotensin } \\
\text { System Inhibitors and } \\
\text { COVID-19 } \\
\text { (SARS-RAS) }\end{array}$ & $\begin{array}{l}\text { Observational, Medical records } \\
\text { Verification whether chronic intake of RAS } \\
\text { inhibitors modifies the prevalence and } \\
\text { severity of the clinical manifestation of } \\
\text { COVID-19. }\end{array}$ & $\begin{array}{l}\text { Patients affected by } \\
\text { COVID-19 referred to } \\
\text { Italian outpatient clinics } \\
\text { or hospitals }\end{array}$ & $\begin{array}{l}\text { To determine whether antihypertensive ACE } \\
\text { inhibitors or ARB increases the severity of } \\
\text { the clinical manifestation of COVID-19 }\end{array}$ \\
\hline
\end{tabular}


of Calu-3 lung cells by SARS-CoV-2 [34]. Previous studies based on SARS and MERS have also shown similar results indicating that inhibition of TMPRSS2 may facilitate reduction of infection of lung cells and therefore may be a suitable therapeutic target for SARS-CoV-2 [117, 118]. Furthermore, development of synthetic inhibitors of TMPRSS2 can also be used to inhibit spike protein activation by TMPRSS2. However, limitations of this candidate is that molecular inhibitors of TMPRSS2 require validation of their specificity against other serine protease and need toxicological studies [119].

Utilizing ACE inhibitors (ACEIs/ARBs) is a topic of major interest for targeting of SARS-CoV-2. ACEIs/ARBs increase ACE2 activation subsequently leading to RAS deregulation. This deregulation may facilitate reduction in acute lung injury, heart injury, and renal damage induced by SARS-CoV-2 [53] However, clinical trials are on-going to provide evidence for the utility of ACE inhibitors for SARS-CoV-2.

Many studies are being published every day indicating various aspects related to therapeutic candidates against SARS-CoV-2. However, since COVID-19 is a new disease, any therapeutics targeting ACE-2 is deliberated until evidence of its efficacy via clinical trials sheds more light on its applicability.

\section{Conclusion}

ACE2 has been identified as a key mediator of entry and subsequent manifestation of pathogenesis in SARS-CoV-2. Several factors such as binding affinity, differential antigenic profiles in spike glycoprotein, ACE2 mutations and risk factors that influence susceptibility to disease have been postulated and implicated in influencing expression and functional activity of ACE2. Furthermore, identification of these factors and their importance in investigating the therapeutic efficacy of ACE2 in SARS-CoV-2 have been highlighted in this review. It is concluded that further large-scale studies keeping these factors in perspective would allow better understanding/management of SARS-CoV-2. Of utmost importance is to focus on studies to understand the role of ACE2 with respect to variation in disease outcome. Stratification of patients with respect to ACE2 and the disease dynamics can then be utilized for personalized therapy with input of sophisticated clinical algorithms to be used for predictive modelling. This approach would allow identification of novel avenues for therapeutic modulation for COVID-19 and future viral diseases.

\section{Acknowledgments}

The publication of this article is supported by the Qatar National Library. This manuscript has been presented as preprint in preprints.org according to the following link: https://www.preprints.org/ manuscript/202009.0420/v1

\section{Author contributions}

CONCEPTION: Lobna Al-Zaidan and Said Dermime

VISUALIZATION: Lobna Al-Zaidan and Afsheen Raza

PREPARATION OF THE MANUSCRIPT: Lobna Al-Zaidan

REVISION FOR IMPORTANT INTELLECTUAL CONTENT: Lobna Al-Zaidan, Sarra Mestiri, Afsheen Raza, Maysaloun Merhi, Varghese Inchakalody, Queenie Fernandes and Nassiba Taib SUPERVISION: Shahab Uddin and Said Dermime 


\section{Ethical considerations}

This study, as a literature review, is exempt of institutional review board approval.

\section{Conflict of interest}

The authors declare that there is no conflict of interest regarding the publication of this article.

\section{References}

[1] Wang C, Horby PW, Hayden FG, Gao GF. A novel coronavirus outbreak of global health concern. Lancet. 2020;395(10223):470-3. doi:10.1016/s0140-6736(20)30185-9

[2] Organization WH. Rolling updates on coronavirus disease (COVID-19) 2020, June 01 [Available from: https://www.who.int/emergencies/diseases/novel-coronavirus-2019/events-as-they-happen.

[3] Chan JF, Yuan S, Kok KH, To KK, Chu H, Yang J, et al. A familial cluster of pneumonia associated with the 2019 novel coronavirus indicating person-to-person transmission: a study of a family cluster. Lancet. 2020;395(10223):514-23. doi:10.1016/s0140-6736(20)30154-9

[4] Liu Z, Xiao X, Wei X, Li J, Yang J, Tan H, et al. Composition and divergence of coronavirus spike proteins and host ACE2 receptors predict potential intermediate hosts of SARS-CoV-2. J Med Virol. 2020. doi:10.1002/jmv.25726

[5] Cui J, Li F, Shi ZL. Origin and evolution of pathogenic coronaviruses. Nat Rev Microbiol. 2019;17(3):181-92. doi:10.1038/s41579-018-0118-9

[6] Hussain S, Pan J, Chen Y, Yang Y, Xu J, Peng Y, et al. Identification of novel subgenomic RNAs and noncanonical transcription initiation signals of severe acute respiratory syndrome coronavirus. J Virol. 2005;79(9):5288-95. doi:10.1128/jvi.79.9.5288-5295.2005

[7] Li Y, Xia L. Coronavirus Disease 2019 (COVID-19): Role of Chest CT in Diagnosis and Management. AJR Am J Roentgenol. 2020;214(6):1280-6. doi:10.2214/ajr.20.22954

[8] Sun P, Lu X, Xu C, Sun W, Pan B. Understanding of COVID-19 based on current evidence. J Med Virol. 2020. doi:10.1002/jmv.25722

[9] Zhou P, Yang XL, Wang XG, Hu B, Zhang L, Zhang W, et al. A pneumonia outbreak associated with a new coronavirus of probable bat origin. Nature. 2020;579(7798):270-3. doi:10.1038/s41586-020-2012-7

[10] Glowacka I, Bertram S, Müller MA, Allen P, Soilleux E, Pfefferle S, et al. Evidence that TMPRSS2 activates the severe acute respiratory syndrome coronavirus spike protein for membrane fusion and reduces viral control by the humoral immune response. $J$ Virol. 2011;85(9):4122-34. doi:10.1128/jvi.02232-10

[11] Verdecchia P, Cavallini C, Spanevello A, Angeli F. The pivotal link between ACE2 deficiency and SARS-CoV-2 infection. Eur J Intern Med. 2020;76:14-20. doi:10.1016/j.ejim.2020.04.037

[12] Harmer D, Gilbert M, Borman R, Clark KL. Quantitative mRNA expression profiling of ACE 2, a novel homologue of angiotensin converting enzyme. FEBS Lett. 2002;532(1-2):107-10. doi:10.1016/s0014-5793(02)03640-2

[13] Hamming I, Timens W, Bulthuis ML, Lely AT, Navis G, van Goor H. Tissue distribution of ACE2 protein, the functional receptor for SARS coronavirus. A first step in understanding SARS pathogenesis. J Pathol. 2004;203(2):631-7. doi:10.1002/path.1570

[14] Lee IT, Nakayama T, Wu CT, Goltsev Y, Jiang S, Gall PA, et al. ACE2 localizes to the respiratory cilia and is not increased by ACE inhibitors or ARBs. Nat Commun. 2020;11(1):5453. doi:10.1038/s41467-020-19145-6

[15] Xu H, Zhong L, Deng J, Peng J, Dan H, Zeng X, et al. High expression of ACE2 receptor of 2019-nCoV on the epithelial cells of oral mucosa. Int J Oral Sci. 2020;12(1):8. doi:10.1038/s41368-020-0074-x

[16] Song J, Li Y, Huang X, Chen Z, Li Y, Liu C, et al. Systematic analysis of ACE2 and TMPRSS2 expression in salivary glands reveals underlying transmission mechanism caused by SARS-CoV-2. J Med Virol. 2020;92(11):255666. doi:10.1002/jmv. 26045

[17] Xiaoqiang Chai LH, Yan Zhang, Weiyu Han, Zhou Lu, Aiwu Ke, Jian Zhou, Guoming Shi, Nan Fang, Jia Fan, Jiabin Cai, Jue Fan, Fei Lan. Specific ACE2 Expression in Cholangiocytes May Cause Liver Damage After 2019-nCoV Infection. BioRXiv. 2020. doi:https://doi.org/10.1101/2020.02.03.931766

[18] Qi J, Zhou Y, Hua J, Zhang L, Bian J, Liu B, et al. The scRNA-seq Expression Profiling of the Receptor ACE2 and the Cellular Protease TMPRSS2 Reveals Human Organs Susceptible to SARS-CoV-2 Infection. Int J Environ Res Public Health. 2021;18(1). doi:10.3390/ijerph18010284 
[19] Pan XW, Xu D, Zhang H, Zhou W, Wang LH, Cui XG. Identification of a potential mechanism of acute kidney injury during the COVID-19 outbreak: a study based on single-cell transcriptome analysis. Intensive Care Med. 2020;46(6):1114-6. doi:10.1007/s00134-020-06026-1

[20] Wang Z, Xu X. scRNA-seq Profiling of Human Testes Reveals the Presence of the ACE2 Receptor, A Target for SARS-CoV-2 Infection in Spermatogonia, Leydig and Sertoli Cells. Cells. 2020;9(4). doi:10.3390/cells9040920

[21] Zupin L, Pascolo L, Zito G, Ricci G, Crovella S. SARS-CoV-2 and the next generations: which impact on reproductive tissues? J Assist Reprod Genet. 2020;37(10):2399-403. doi:10.1007/s10815-020-01917-0

[22] Hikmet F, Méar L, Edvinsson Å, Micke P, Uhlén M, Lindskog C. The protein expression profile of ACE2 in human tissues. Mol Syst Biol. 2020;16(7):e9610. doi:10.15252/msb.20209610

[23] Hui KPY, Cheung MC, Perera R, Ng KC, Bui CHT, Ho JCW, et al. Tropism, replication competence, and innate immune responses of the coronavirus SARS-CoV-2 in human respiratory tract and conjunctiva: an analysis in ex-vivo and in-vitro cultures. Lancet Respir Med. 2020;8(7):687-95. doi:10.1016/s2213-2600(20)30193-4

[24] Zhou L, Xu Z, Castiglione GM, Soiberman US, Eberhart CG, Duh EJ. ACE2 and TMPRSS2 are expressed on the human ocular surface, suggesting susceptibility to SARS-CoV-2 infection. Ocul Surf. 2020;18(4):537-44. doi:10.1016/j.jtos.2020.06.007

[25] Al-Benna S. Association of high level gene expression of ACE2 in adipose tissue with mortality of COVID-19 infection in obese patients. Obes Med. 2020;19:100283. doi:10.1016/j.obmed.2020.100283

[26] Leung JM, Yang CX, Tam A, Shaipanich T, Hackett TL, Singhera GK, et al. ACE-2 expression in the small airway epithelia of smokers and COPD patients: implications for COVID-19. Eur Respir J. 2020;55(5). doi:10.1183/13993003.00688-2020

[27] Grasselli G, Zangrillo A, Zanella A, Antonelli M, Cabrini L, Castelli A, et al. Baseline Characteristics and Outcomes of 1591 Patients Infected With SARS-CoV-2 Admitted to ICUs of the Lombardy Region, Italy. JAMA. 2020;323(16):1574-81. doi:10.1001/jama.2020.5394

[28] Wu C, Chen X, Cai Y, Xia J, Zhou X, Xu S, et al. Risk Factors Associated With Acute Respiratory Distress Syndrome and Death in Patients With Coronavirus Disease 2019 Pneumonia in Wuhan, China. JAMA Intern Med. 2020. doi:10.1001/jamainternmed.2020.0994

[29] Yang J, Zheng Y, Gou X, Pu K, Chen Z, Guo Q, et al. Prevalence of comorbidities and its effects in patients infected with SARS-CoV-2: a systematic review and meta-analysis. International Journal of Infectious Diseases. 2020;94:91-5. doi:https://doi.org/10.1016/j.ijid.2020.03.017

[30] Patel VB, Zhong JC, Grant MB, Oudit GY. Role of the ACE2/Angiotensin 1-7 Axis of the Renin-Angiotensin System in Heart Failure. Circ Res. 2016;118(8):1313-26. doi:10.1161/circresaha.116.307708

[31] Patel SK, Velkoska E, Freeman M, Wai B, Lancefield TF, Burrell LM. From gene to protein-experimental and clinical studies of ACE2 in blood pressure control and arterial hypertension. Front Physiol. 2014;5:227. doi:10.3389/fphys.2014.00227

[32] Zhong J, Basu R, Guo D, Chow FL, Byrns S, Schuster M, et al. Angiotensin-converting enzyme 2 suppresses pathological hypertrophy, myocardial fibrosis, and cardiac dysfunction. Circulation. 2010;122(7):717-28, pp. 18. following 28. doi:10.1161/circulationaha.110.955369

[33] Wang W, Patel VB, Parajuli N, Fan D, Basu R, Wang Z, et al. Heterozygote loss of ACE2 is sufficient to increase the susceptibility to heart disease. J Mol Med (Berl). 2014;92(8):847-58. doi:10.1007/s00109-014-1149-y

[34] Hoffmann M, Kleine-Weber H, Schroeder S, Krüger N, Herrler T, Erichsen S, et al. SARS-CoV-2 Cell Entry Depends on ACE2 and TMPRSS2 and Is Blocked by a Clinically Proven Protease Inhibitor. Cell. 2020;181(2):271-80.e8. doi:10.1016/j.cell.2020.02.052

[35] Walls AC, Park YJ, Tortorici MA, Wall A, McGuire AT, Veesler D. Structure, Function, and Antigenicity of the SARS-CoV-2 Spike Glycoprotein. Cell. 2020;181(2):281-92.e6. doi:10.1016/j.cell.2020.02.058

[36] Verdecchia P, Cavallini C, Spanevello A, Angeli F. The pivotal link between ACE2 deficiency and SARS-CoV-2 infection. Eur J Intern Med. 2020. doi:10.1016/j.ejim.2020.04.037

[37] [The epidemiological characteristics of an outbreak of 2019 novel coronavirus diseases (COVID-19) in China]. Zhonghua Liu Xing Bing Xue Za Zhi. 2020;41(2):145-51. doi:10.3760/cma.j.issn.0254-6450.2020.02.003

[38] Agata J, Ura N, Yoshida H, Shinshi Y, Sasaki H, Hyakkoku M, et al. Olmesartan is an angiotensin II receptor blocker with an inhibitory effect on angiotensin-converting enzyme. Hypertens Res. 2006;29(11):865-74. doi:10.1291/hypres.29.865

[39] Ferrario CM, Jessup J, Chappell MC, Averill DB, Brosnihan KB, Tallant EA, et al. Effect of angiotensin-converting enzyme inhibition and angiotensin II receptor blockers on cardiac angiotensin-converting enzyme 2. Circulation. 2005;111(20):2605-10. doi:10.1161/circulationaha.104.510461 
[40] Santos RAS, Sampaio WO, Alzamora AC, Motta-Santos D, Alenina N, Bader M, et al. The ACE2/Angiotensin(1-7)/MAS Axis of the Renin-Angiotensin System: Focus on Angiotensin-(1-7). Physiol Rev. 2018;98(1):505-53. doi:10.1152/physrev.00023.2016

[41] Namsolleck P, Recarti C, Foulquier S, Steckelings UM, Unger T. AT(2) receptor and tissue injury: therapeutic implications. Curr Hypertens Rep. 2014;16(2):416. doi:10.1007/s11906-013-0416-6

[42] Kuba K, Imai Y, Rao S, Gao H, Guo F, Guan B, et al. A crucial role of angiotensin converting enzyme 2 (ACE2) in SARS coronavirus-induced lung injury. Nat Med. 2005;11(8):875-9. doi:10.1038/nm1267

[43] Dijkman R, Jebbink MF, Deijs M, Milewska A, Pyrc K, Buelow E, et al. Replication-dependent downregulation of cellular angiotensin-converting enzyme 2 protein expression by human coronavirus NL63. J Gen Virol. 2012;93(Pt 9):1924-9. doi:10.1099/vir.0.043919-0

[44] Kreutz R, Algharably EAE, Azizi M, Dobrowolski P, Guzik T, Januszewicz A, et al. Hypertension, the renin-angiotensin system, and the risk of lower respiratory tract infections and lung injury: implications for COVID-19. Cardiovasc Res. 2020. doi:10.1093/cvr/cvaa097

[45] Oyelade T, Alqahtani J, Canciani G. Prognosis of COVID-19 in Patients with Liver and Kidney Diseases: An Early Systematic Review and Meta-Analysis. Trop Med Infect Dis. 2020;5(2). doi:10.3390/tropicalmed5020080

[46] Zhen Li MW, Jiwei Yao, Jie Guo, Xiang Liao, Siji Song, Jiali Li, Guangjie Duan, Yuanxiu Zhou, Xiaojun Wu, Zhansong Zhou, Taojiao Wang, Ming Hu, Xianxiang Chen, Yu Fu, Chong Lei, Hailong Dong, Chuou Xu, Yahua Hu, Min Han, Yi Zhou, Hongbo Jia, Xiaowei Chen, Junan Yan. Caution on Kidney Dysfunctions of COVID-19 Patients. MedRXiv. 2020, March 27 doi:10.1101/2020.02.08.20021212

[47] Fang L, Karakiulakis G, Roth M. Are patients with hypertension and diabetes mellitus at increased risk for COVID-19 infection? Lancet Respir Med. 2020;8(4):e21. doi:10.1016/s2213-2600(20)30116-8

[48] Peng YD, Meng K, Guan HQ, Leng L, Zhu RR, Wang BY, et al. [Clinical characteristics and outcomes of 112 cardiovascular disease patients infected by 2019-nCoV]. Zhonghua Xin Xue Guan Bing Za Zhi. 2020;48(0):E004. doi:10.3760/cma.j.cn112148-20200220-00105

[49] Simonnet A, Chetboun M, Poissy J, Raverdy V, Noulette J, Duhamel A, et al. High prevalence of obesity in severe acute respiratory syndrome coronavirus-2 (SARS-CoV-2) requiring invasive mechanical ventilation. Obesity (Silver Spring). 2020. doi:10.1002/oby.22831

[50] Health LDo. Louisiana Department of Health Updates for 3/31/2020 2020, March 31 [Available from: http://ldh.la.gov/index.cfm/newsroom/detail/5522.

[51] Li MY, Li L, Zhang Y, Wang XS. Expression of the SARS-CoV-2 cell receptor gene ACE2 in a wide variety of human tissues. Infect Dis Poverty. 2020;9(1):45. doi:10.1186/s40249-020-00662-X

[52] Xiaodong Jia CY, Shanshan Lu, Yan Chen, Qingyan Liu, Junfan Bai, Yinying Lu. Two Things about COVID-19 Might Need Attention. Preprints 2020. 2020, February 23. doi:10.20944/preprints202002.0315.v1

[53] Guo J, Huang Z, Lin L, Lv J. Coronavirus Disease 2019 (COVID-19) and Cardiovascular Disease: A Viewpoint on the Potential Influence of Angiotensin-Converting Enzyme Inhibitors/Angiotensin Receptor Blockers on Onset and Severity of Severe Acute Respiratory Syndrome Coronavirus 2 Infection. J Am Heart Assoc. 2020;9(7):e016219. doi:10.1161/jaha.120.016219

[54] Ryan PM, Caplice NM. Is Adipose Tissue a Reservoir for Viral Spread, Immune Activation, and Cytokine Amplification in Coronavirus Disease 2019? Obesity (Silver Spring). 2020. doi:10.1002/oby.22843

[55] Kassir R. Risk of COVID-19 for patients with obesity. Obes Rev. 2020;21(6):e13034. doi:10.1111/obr.13034

[56] Cai G, Bossé Y, Xiao F, Kheradmand F, Amos CI. Tobacco Smoking Increases the Lung Gene Expression of ACE2, the Receptor of SARS-CoV-2. Am J Respir Crit Care Med. 2020. doi:10.1164/rccm.202003-0693LE

[57] Xie X, Xudong X, Chen J, Junzhu C, Wang X, Xingxiang W, et al. Age- and gender-related difference of ACE2 expression in rat lung. Life Sci. 2006;78(19):2166-71. doi:10.1016/j.lfs.2005.09.038

[58] Xie J, Tong Z, Guan X, Du B, Qiu H. Clinical Characteristics of Patients Who Died of Coronavirus Disease 2019 in China. JAMA Netw Open. 2020;3(4):e205619. doi:10.1001/jamanetworkopen.2020.5619

[59] Meng Y, Wu P, Lu W, Liu K, Ma K, Huang L, et al. Sex-specific clinical characteristics and prognosis of coronavirus disease-19 infection in Wuhan, China: A retrospective study of 168 severe patients. PLoS Pathog. 2020;16(4):e1008520. doi:10.1371/journal.ppat.1008520

[60] Huang C, Wang Y, Li X, Ren L, Zhao J, Hu Y, et al. Clinical features of patients infected with 2019 novel coronavirus in Wuhan, China. Lancet. 2020;395(10223):497-506. doi:10.1016/s0140-6736(20)30183-5

[61] Onder G, Rezza G, Brusaferro S. Case-Fatality Rate and Characteristics of Patients Dying in Relation to COVID-19 in Italy. Jama. 2020. doi:10.1001/jama.2020.4683 
[62] Aditi Shastri JW, Sachee Agrawal, Nirjhar Chaterjee, Kith Pradhan, Mendel Goldfinger, Noah Kornblum, Ulrich Steidl, Amit Verma, Jayanthi Shastri. Delayed clearance of SARS-CoV2 in male compared to female patients: High ACE2 expression in testes suggests possible existence of gender-specific viral reservoirs. MedRXiv 2020, April 17. doi:10.1101/2020.04.16.20060566

[63] Ling Ma WX, Danyang Li, Lei Shi, Yanhong Mao, Yao Xiong, Yuanzhen Zhang, Ming Zhang. Effect of SARS-CoV-2 infection upon male gonadal function: A single centerbased study. medRxiv. 2020, March 30. doi:10.1101/2020.03.21.20037267

[64] Joyner J, Neves LA, Granger JP, Alexander BT, Merrill DC, Chappell MC, et al. Temporal-spatial expression of ANG(1-7) and angiotensin-converting enzyme 2 in the kidney of normal and hypertensive pregnant rats. Am J Physiol Regul Integr Comp Physiol. 2007;293(1):R169-77. doi:10.1152/ajpregu.00387.2006

[65] Levy A, Yagil Y, Bursztyn M, Barkalifa R, Scharf S, Yagil C. ACE2 expression and activity are enhanced during pregnancy. Am J Physiol Regul Integr Comp Physiol. 2008;295(6):R1953-61. doi:10.1152/ajpregu.90592.2008

[66] Valdés G, Neves LA, Anton L, Corthorn J, Chacón C, Germain AM, et al. Distribution of angiotensin(1-7) and ACE2 in human placentas of normal and pathological pregnancies. Placenta. 2006;27(2-3):200-7. doi:10.1016/j.placenta.2005.02.015

[67] Jing Y, Run-Qian L, Hao-Ran W, Hao-Ran C, Ya-Bin L, Yang G, et al. Potential influence of COVID-19/ACE2 on the female reproductive system. Mol Hum Reprod. 2020. doi:10.1093/molehr/gaaa030

[68] Zhao X, Jiang Y, Zhao Y, Xi H, Liu C, Qu F, et al. Analysis of the susceptibility to COVID-19 in pregnancy and recommendations on potential drug screening. Eur J Clin Microbiol Infect Dis. 2020:1-12. doi:10.1007/s10096-02003897-6

[69] Li M, Chen L, Zhang J, Xiong C, Li X. The SARS-CoV-2 receptor ACE2 expression of maternal-fetal interface and fetal organs by single-cell transcriptome study. PLoS One. 2020;15(4):e0230295. doi:10.1371/journal.pone.0230295

[70] Yeoh CB, Lee KJ, Rieth EF, Mapes R, Tchoudovskaia AV, Fischer GW, et al. COVID-19 in the Cancer Patient. Anesth Analg. 2020;131(1):16-23. doi:10.1213/ane.0000000000004884

[71] Guignabert C, de Man F, Lombès M. ACE2 as therapy for pulmonary arterial hypertension: the good outweighs the bad. Eur Respir J. 2018;51(6). doi:10.1183/13993003.00848-2018

[72] Benigni A, Cassis P, Remuzzi G. Angiotensin II revisited: new roles in inflammation, immunology and aging. $E M B O$ Mol Med. 2010;2(7):247-57. doi:10.1002/emmm.201000080

[73] Rodrigues Prestes TR, Rocha NP, Miranda AS, Teixeira AL, Simoes ESAC. The Anti-Inflammatory Potential of ACE2/Angiotensin-(1-7)/Mas Receptor Axis: Evidence from Basic and Clinical Research. Curr Drug Targets. 2017;18(11):1301-13. doi:10.2174/1389450117666160727142401

[74] Winkler T, Ben-David U. Elevated expression of ACE2 in tumor-adjacent normal tissues of cancer patients. Int $J$ Cancer. 2020;147(11):3264-6. doi:10.1002/ijc.33145

[75] Wu C, Liu Y, Yang Y, Zhang P, Zhong W, Wang Y, et al. Analysis of therapeutic targets for SARS-CoV-2 and discovery of potential drugs by computational methods. Acta Pharm Sin B. 2020. doi:10.1016/j.apsb.2020.02.008

[76] Wang Q, Zhang Y, Wu L, Niu S, Song C, Zhang Z, et al. Structural and Functional Basis of SARS-CoV-2 Entry by Using Human ACE2. Cell. 2020;181(4):894-904.e9. doi:10.1016/j.cell.2020.03.045

[77] Bianchi MBD, Giovanetti M, Angeletti S, Ciccozzi M, Pascarella S. Sars-CoV-2 Envelope and Membrane Proteins: Differences from Closely Related Proteins Linked to Cross-species Transmission? Preprints 2020. 2020 , May 08. doi:10.20944/preprints202004.0089.v1

[78] EA JA, Jones IM. Membrane binding proteins of coronaviruses. Future Virol. 2019;14(4):275-86. doi:10.2217/fvl2018-0144

[79] Coutard B, Valle C, de Lamballerie X, Canard B, Seidah NG, Decroly E. The spike glycoprotein of the new coronavirus 2019-nCoV contains a furin-like cleavage site absent in $\mathrm{CoV}$ of the same clade. Antiviral Res. 2020;176:104742. doi:10.1016/j.antiviral.2020.104742

[80] Yan R, Zhang Y, Li Y, Xia L, Guo Y, Zhou Q. Structural basis for the recognition of SARS-CoV-2 by full-length human ACE2. Science. 2020;367(6485):1444-8. doi:10.1126/science.abb2762

[81] Li F, Li W, Farzan M, Harrison SC. Structure of SARS coronavirus spike receptor-binding domain complexed with receptor. Science. 2005;309(5742):1864-8. doi:10.1126/science.1116480

[82] Han X, Qi J, Song H, Wang Q, Zhang Y, Wu Y, et al. Structure of the S1 subunit C-terminal domain from bat-derived coronavirus HKU5 spike protein. Virology. 2017;507:101-9. doi:10.1016/j.virol.2017.04.016

[83] Lan J, Ge J, Yu J, Shan S, Zhou H, Fan S, et al. Structure of the SARS-CoV-2 spike receptor-binding domain bound to the ACE2 receptor. Nature. 2020;581(7807):215-20. doi:10.1038/s41586-020-2180-5

[84] Towler P, Staker B, Prasad SG, Menon S, Tang J, Parsons T, et al. ACE2 X-ray structures reveal a large hinge-bending motion important for inhibitor binding and catalysis. J Biol Chem. 2004;279(17):17996-8007. doi:10.1074/jbc.M311191200 
[85] Shang J, Ye G, Shi K, Wan Y, Luo C, Aihara H, et al. Structural basis of receptor recognition by SARS-CoV-2. Nature. 2020;581(7807):221-4. doi:10.1038/s41586-020-2179-y

[86] Wrapp D, Wang N, Corbett KS, Goldsmith JA, Hsieh CL, Abiona O, et al. Cryo-EM structure of the 2019-nCoV spike in the prefusion conformation. Science. 2020;367(6483):1260-3. doi:10.1126/science.abb2507

[87] Belouzard S, Millet JK, Licitra BN, Whittaker GR. Mechanisms of coronavirus cell entry mediated by the viral spike protein. Viruses. 2012;4(6):1011-33. doi:10.3390/v4061011

[88] BANK NG. S protein [SARS coronavirus Urbani] GenBank: AAP13441.1 [GenBank: AAP13441.1]. Available from: https://www.ncbi.nlm.nih.gov/protein/AAP13441.1.

[89] BANK NG. surface glycoprotein [Severe acute respiratory syndrome coronavirus 2] GenBank: QHD43416.1 [GenBank: QHD43416.1]. Available from: https://www.ncbi.nlm.nih.gov/protein/QHD43416.1.

[90] Chunyun Sun LC, Ji Yang, Chunxia Luo, Yanjing Zhang, Jing Li, Jiahui Yang, Jie Zhang, Liangzhi Xie. SARS-CoV-2 and SARS-CoV Spike-RBD Structure and Receptor Binding Comparison and Potential Implications on Neutralizing Antibody and Vaccine Development. BioRXiv. 2020, February 20. doi:10.1101/2020.02.16.951723

[91] Tay MZ, Poh CM, Rénia L, MacAry PA, Ng LFP. The trinity of COVID-19: immunity, inflammation and intervention. Nat Rev Immunol. 2020;20(6):363-74. doi:10.1038/s41577-020-0311-8

[92] Tian X, Li C, Huang A, Xia S, Lu S, Shi Z, et al. Potent binding of 2019 novel coronavirus spike protein by a SARS coronavirus-specific human monoclonal antibody. Emerg Microbes Infect. 2020;9(1):382-5. doi:10.1080/22221751.2020.1729069

[93] Zhu Z, Chakraborti S, He Y, Roberts A, Sheahan T, Xiao X, et al. Potent cross-reactive neutralization of SARS coronavirus isolates by human monoclonal antibodies. Proc Natl Acad Sci U S A. 2007;104(29):12123-8. doi:10.1073/pnas.0701000104

[94] Yuan M, Wu NC, Zhu X, Lee CD, So RTY, Lv H, et al. A highly conserved cryptic epitope in the receptor binding domains of SARS-CoV-2 and SARS-CoV. Science. 2020;368(6491):630-3. doi:10.1126/science.abb7269

[95] Wang C, Li W, Drabek D, Okba NMA, van Haperen R, Osterhaus A, et al. A human monoclonal antibody blocking SARS-CoV-2 infection. Nat Commun. 2020;11(1):2251. doi:10.1038/s41467-020-16256-y

[96] Lv H, Wu NC, Tsang OT, Yuan M, Perera R, Leung WS, et al. Cross-reactive Antibody Response between SARS-CoV-2 and SARS-CoV Infections. Cell Rep. 2020;31(9):107725. doi:10.1016/j.celrep.2020.107725

[97] Cheng Y, Wong R, Soo YO, Wong WS, Lee CK, Ng MH, et al. Use of convalescent plasma therapy in SARS patients in Hong Kong. Eur J Clin Microbiol Infect Dis. 2005;24(1):44-6. doi:10.1007/s10096-004-1271-9

[98] Zheng M, Song L. Novel antibody epitopes dominate the antigenicity of spike glycoprotein in SARS-CoV-2 compared to SARS-CoV. Cell Mol Immunol. 2020;17(5):536-8. doi:10.1038/s41423-020-0385-z

[99] Vipul Kumar JS, Seyed E. Hasnain, Durai Sundar. Possible link between higher transmissibility of B.1.617 and B.1.1.7 variants of SARS-CoV-2 and increased structural stability of its spike protein and hACE2 affinity. BioRXiv. 2021. doi:https://doi.org/10.1101/2021.04.29.441933

[100] Eric W. Stawiski DD, Kushal Suryamohan, Ravi Gupta, Frederic A. Fellouse, J. Fah Sathirapongsasuti, Jiang Liu, YingPing Jiang, Aakrosh Ratan, Monika Mis, Devi Santhosh, Sneha Somasekar, Sangeetha Mohan, Sameer Phalke, Boney Kuriakose, Aju Antony, Jagath R. Junutula, Stephan C. Schuster, Natalia Jura, Somasekar Seshagiri. Human ACE2 receptor polymorphisms predict SARS-CoV-2 susceptibility. BioRXiv. 2020, April 10. doi:10.1101/2020.04.07.024752

[101] Chiu RW, Tang NL, Hui DS, Chung GT, Chim SS, Chan KC, et al. ACE2 gene polymorphisms do not affect outcome of severe acute respiratory syndrome. Clin Chem. 2004;50(9):1683-6. doi:10.1373/clinchem.2004.035436

[102] Itoyama S, Keicho N, Hijikata M, Quy T, Phi NC, Long HT, et al. Identification of an alternative 5'-untranslated exon and new polymorphisms of angiotensin-converting enzyme 2 gene: lack of association with SARS in the Vietnamese population. Am J Med Genet A. 2005;136(1):52-7. doi:10.1002/ajmg.a.30779

[103] Devaux CA, Rolain JM, Raoult D. ACE2 receptor polymorphism: Susceptibility to SARS-CoV-2, hypertension, multi-organ failure, and COVID-19 disease outcome. J Microbiol Immunol Infect. 2020;53(3):425-35. doi:10.1016/j.jmii.2020.04.015

[104] Trials NC. Clinical Trials [Available from: https://clinicaltrials.gov/.

[105] Changhai Lei WF, Kewen Qian, Tian Li, Sheng Zhang, Min Ding, Shi Hu. Potent neutralization of 2019 novel coronavirus by recombinant ACE2-Ig. BioRXiv. 2020, February 03. doi:10.1101/2020.02.01.929976

[106] Monteil V, Kwon H, Prado P, Hagelkrüys A, Wimmer RA, Stahl M, et al. Inhibition of SARS-CoV-2 Infections in Engineered Human Tissues Using Clinical-Grade Soluble Human ACE2. Cell. 2020;181(4):905-13.e7. doi:10.1016/j.cell.2020.04.004

[107] Zhang J, Xie B, Hashimoto K. Current status of potential therapeutic candidates for the COVID-19 crisis. Brain Behav Immun. 2020. doi:10.1016/j.bbi.2020.04.046 
[108] Guo L, Bi W, Wang X, Xu W, Yan R, Zhang Y, et al. Engineered trimeric ACE2 binds viral spike protein and locks it in "Three-up" conformation to potently inhibit SARS-CoV-2 infection. Cell Res. 2021;31(1):98-100. doi:10.1038/s41422-020-00438-w

[109] Gilbert TL, Brown JR, O'Hara PJ, Buroker NE, Beckenbach AT, Smith MJ. Sequence of tRNA(Thr) and tRNA(Pro) from white sturgeon (Acipenser transmontanus) mitochondria. Nucleic Acids Res. 1988;16(24):11825. doi:10.1093/nar/16.24.11825

[110] Nadeem MS, Zamzami MA, Choudhry H, Murtaza BN, Kazmi I, Ahmad H, et al. Origin, Potential Therapeutic Targets and Treatment for Coronavirus Disease (COVID-19). Pathogens. 2020;9(4). doi:10.3390/pathogens9040307

[111] Kruse RL. Therapeutic strategies in an outbreak scenario to treat the novel coronavirus originating in Wuhan, China. F1000Res. 2020;9:72. doi:10.12688/f1000research.22211.2

[112] Henry BM, De Oliveira MHS, Benoit S, Plebani M, Lippi G. Hematologic, biochemical and immune biomarker abnormalities associated with severe illness and mortality in coronavirus disease 2019 (COVID-19): a meta-analysis. Clinical Chemistry and Laboratory Medicine (CCLM). 2020;58(7):1021-8.

[113] Yuan M, Wan Y, Liu C, Li Y, Liu Z, Lin C, et al. Identification and characterization of a monoclonal antibody blocking the SARS-CoV-2 spike protein-ACE2 interaction. Cell Mol Immunol. 2021;18(6):1562-4. doi:10.1038/s41423-02100684- $x$

[114] Ge J, Wang R, Ju B, Zhang Q, Sun J, Chen P, et al. Antibody neutralization of SARS-CoV-2 through ACE2 receptor mimicry. Nat Commun. 2021;12(1):250. doi:10.1038/s41467-020-20501-9

[115] Chen Y, Zhang Y, Yan R, Wang G, Zhang Y, Zhang Z, et al. ACE2-Targeting Monoclonal Antibody As A" Pan" Coronavirus Blocker In Vitro and In A Mouse Model. bioRxiv. 2020.

[116] Markus Hoffmann HK-W, Nadine Krüger, Marcel Müller, Christian Drosten, Stefan Pöhlmann. The novel coronavirus 2019 (2019-nCoV) uses the SARS-coronavirus receptor ACE2 and the cellular protease TMPRSS2 for entry into target cells. bioRXiv. 2020, January 31. doi:10.1101/2020.01.31.929042

[117] Sakai K, Ami Y, Tahara M, Kubota T, Anraku M, Abe M, et al. The host protease TMPRSS2 plays a major role in in vivo replication of emerging H7N9 and seasonal influenza viruses. J Virol. 2014;88(10):5608-16. doi:10.1128/jvi.03677-13

[118] Iwata-Yoshikawa N, Okamura T, Shimizu Y, Hasegawa H, Takeda M, Nagata N. TMPRSS2 Contributes to Virus Spread and Immunopathology in the Airways of Murine Models after Coronavirus Infection. J Virol. 2019;93(6). doi:10.1128/jvi.01815-18

[119] Dorothea Bestle MRH, Hannah Limburg, Thuy Van Lam van, Oliver Pilgram, Hong Moulton, David A. Stein, Kornelia Hardes, Markus Eickmann, Olga Dolnik, Cornelius Rohde, Stephan Becker, Hans-Dieter Klenk, Wolfgang Garten, Torsten Steinmetzer, Eva Böttcher-Friebertshäuser. TMPRSS2 and furin are both essential for proteolytic activation and spread of SARS-CoV-2 in human airway epithelial cells and provide promising drug targets. BioRXiv. 2020, April 15. doi:10.1101/2020.04.15.042085

[120] Kirchdoerfer RN, Wang N, Pallesen J, Wrapp D, Turner HL, Cottrell CA, et al. Stabilized coronavirus spikes are resistant to conformational changes induced by receptor recognition or proteolysis. Sci Rep. 2018;8(1):15701. doi:10.1038/s41598-018-34171-7 